\title{
HOOKWORM INFECTION;
}

\section{ITS CORRELATION WITH PACKED CELL VOLUME IN A RURAL COMMUNITY OF PAKISTAN}

\author{
DR. MUGHEES ANJUM, MBBS, M.Phil \\ Assistant Professor of Community Medicine, \\ Qaid-E-Azam Medical College Bahawalpur.
}

\begin{abstract}
This study correlation of hookworm infection and packed cell volume, was conducted in rural population of Mustafaabad (Lulliani) District Kasur. Through a stratified random sampling 1010 adult male subjects were selected from the locality.253.ie; $25.05 \%$ were found hookworm positive. The positive cases were subjected to detailed stool examination and blood examination. A thorough study was conducted on 253 hookworm positive cases for correlation of PCV and No. of hookworm ova per gram of faeces, with coefficient of correlation as $\mathrm{r}=-0.841$, being a high degree of negative correlation.
\end{abstract}

\section{INTRODUCTION}

Hookworm infection is a great public health problem and produces the serious human disease by producing blood loss and in this way can lead to serious man power and economic loss among people of rural population. Hookworm infection prevails in warm and humid areas of the world where partly shaded sandy and moist soil is present $^{15}$.

Millions of people of the world are prey to this notorious infection. Many studies conducted in Pakistan show that hookworm infection is prevalent in Pakistan ${ }^{6 " 10}$.

It has also been observed that the species present in Pakistan is Ancylostoma duodenale. It is more dangerous as far as its blood sucking ability as compared to Necator americanus.

Under the above circumstances it has been emphasized by many scientists to perform research on human hookworm infection especially on details of blood loss. Many studies conducted so for show that correlation of hookworm infection and PCVdoes exist1114. A number of workers did not find any relationship between hookworm infection and $\mathrm{PCV}^{15-18}$.

\section{AIMS AND OBJECTIVES}

1. To find out the prevalence of hookworm ; infection in the rural community of Pakistan.

2. To find out that whether a correlation of hookworm infection and PCV exists or not in rural area of Pakistan.

\section{MATERIALS AND METHODS}

On the basis of stratified random sampling method 1010 male adult subjects were selected from rural area of Mustafaabad (Lulliani) Distt. Kasur. 
Out of these 1010 subjects 253 were found hookworm positive. All hookworm positive cases were subjected to detailed parasitological and haematological tests. After macroscopic examination of stool microscopic examination was carried out 19. Quantitative estimation of hookworm eggs in faeces by Stall's modified egg counting technique was done ${ }^{20}$.

The blood samples were collected under strictaseptic technique21. Packed cell volume was determined by micro haematrocit method ${ }^{22 " 23}$.

\section{RESULTS}

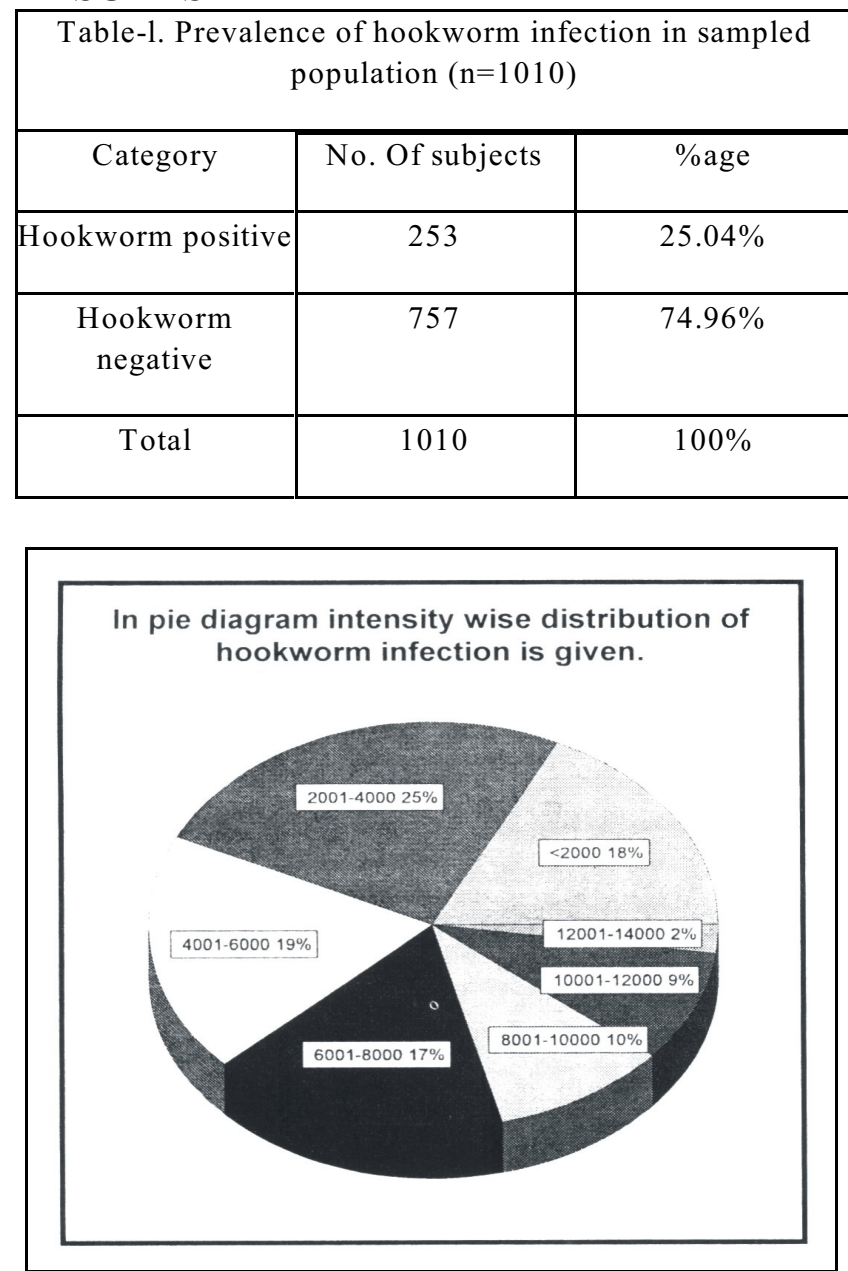

In this Graph there is linear negative or inverse correlation between PCV values in percentage and intensity of hookworm infection in terms of No. of ova per gram of faeces.

\section{DISCUSSION}

This study has shown a high degree of negative correlation between hookworm infection and PCV, $(\mathrm{r}=--0.841)$. This study has therefore opened up the chapter of supporting the previous studies in favour of relationship between hookworm infection and PCV values and contradicting those which could not find any relationship.

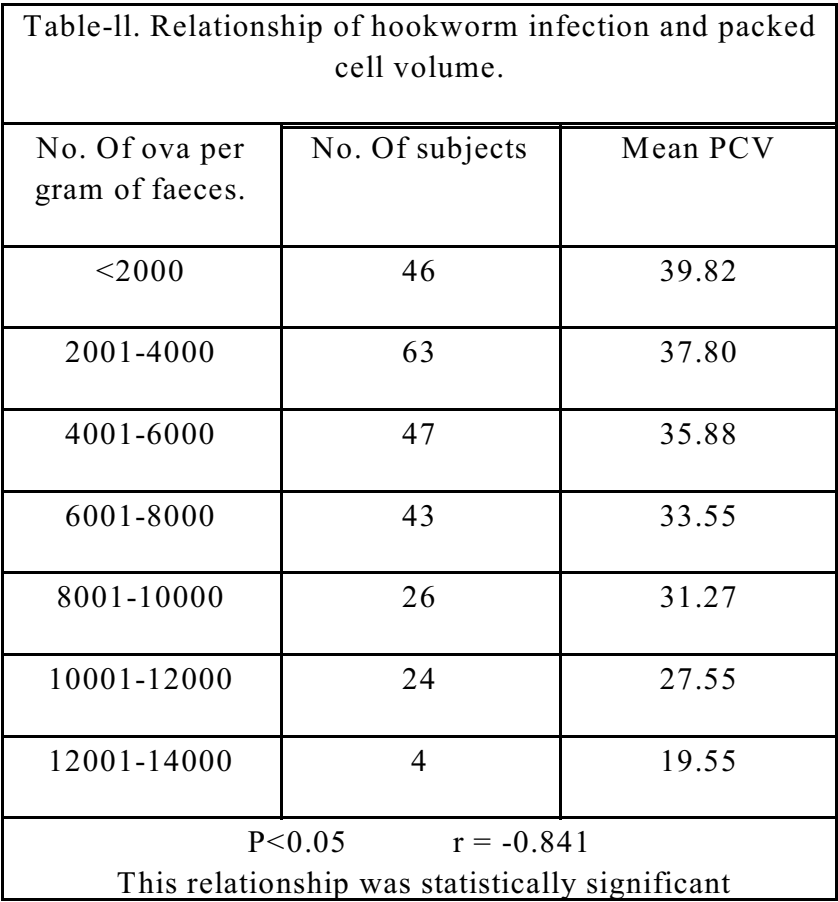

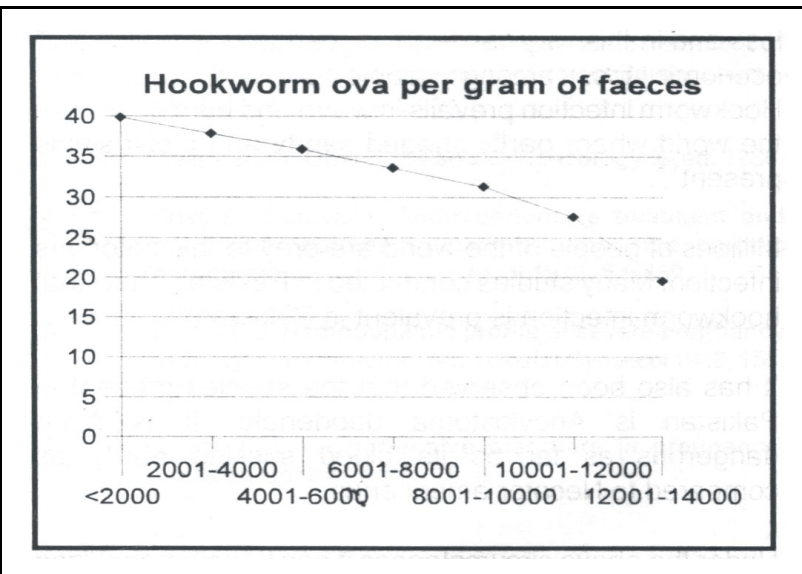


In many studies which did not find any relationship between hookworm infection and PCV, no statistical analysis was made ( Roche and Layrisse ${ }^{11}$ Ansari, and $\mathrm{Naru}^{7}$ Basta et $\mathrm{al}^{14}, \mathrm{WHO}^{25}$ Gold Simith $^{26}$ ) some studies who did not find any relationship reveal that the sample size was too small (Roche and Layrisse ${ }^{11}$, Kennedy ${ }^{15}$, Foy and Kondi $^{16}$, Stott $\left.{ }^{17}\right)$.

Perusal of the above shows that studies which don't show any relationship between hookworm infection and PCV, either used small sample size or their studies did not carry all spectrum of cases and data was not subjected to statistical treatment.

In the present study it has been established and proved that there does exist a negative correlation of high degree between PCV and No. of ova per gram of faeces.

\section{REFERENCES}

1. Desowitz, R.S; Ova and parasites. 1st.Ed.Harper \& Row publications lnc.2350.Virginia Avenue, Hagers town, Maryland, 21740, U.S.A. 121-126.1980.

2. W.H.O; Intestinal protozoa and helminthic infections. Report of W.H.O; Scientific group. Technical report series 666:1-25.1981.

3. Beaver, P; C; Jung, R. C, and Cupp. E. WL; Clinical parasitology 9th.Ed.Lea and Fabiger, Philadelphia: 269-287.1984.

4. Oyerinde, J.P.O. Human Ancylostoma infections in igeria. Ann.Trop.Med.Parasitol;22(A):263367.1987.

5. Doby.J.M; Importance of tropical parasites to temperate regions. $3 \mathrm{fd}$ European Multicolloquim of Parasitilogy workshop No.15, Parasitic; 82;191203.1981.

6. Naru, N.A; Intestinal parasitic infections of Pakistan. Pak.Jr. Hlth;23:11-18.1973.

7. Ansari, M.A.R; and Naru, N.A: Some incoming intestinal parasites of Lahore. Pak. Jr. Med. Res.6(2): 138-154.1968.

8. Ansari, M.A. R;Naru, N.A and Chaudhry, M.A; A preliminary report on the intestinal parasites of Lulliani, District Lahore, Pak.Jr.Hlth; 18(2):5772.1968

9. Bano, L and Yasmeen, B; Observations on incidence of infection with intestinal parasites in school children of Peshawar.Pak.Jr.Med.Res;19(4):6667.1981 .

10. Pal, R.A; and Rana, S.I; Incidence of intestinal helminthic parasites of man in twin cities of Rawalpindi Islamabad, Jr. Pak, Med. Assoc.33:33.1983.

11. Roche, $\mathrm{M}$; and Layrisse, $\mathrm{M}$; The nature and causes o f $\mathrm{h}$ o 0 k $\mathrm{w}$ o $\mathrm{r}$ m a $\mathrm{n}$ a e $\mathrm{m} \mathrm{i}$ a. Amr.Jr.Trop.Med.Hyg;15:1031-1102-1966.

12. White,PL,Quiroz, A; Gonzalez- Mugaburu, I; Morales; S; Atkins, J; Collazons.G; and Hegsted.D.M: Effects of iron treatment of anaemia in a tropical area. Amr.Jr.Clin.Nutr;5:621-628.1957.

13. Farid, $\mathrm{Z}$ and Maile, A; Treatment of hookworm infection in Egypt with Buphenium hydroxynaphthoate and the relationship between iron deficiency anaemia and intensity of infection. Amr. Jr. Trop. Med. 11:497-505-1962.

14. Basta, S.S; Soerkirman, K.D and Scrim shaw, N. S: Iron deficiency anaemia and productivity of adult males in Indonesia. Jr.CI.Nut;32:916-226.1979.

15. Kennedy, A.F; Some aspects of hookworm carrier state in Africian Mine Workers, central African Medical ' Jr;2:104-106.1956.

16. Foy, H and Kondi; A. Hookworm in the aetiology of tropical Iron deficiency anaemia. Trans. Roy.Soc. Trop.Med.Hyg;54;419.1960.

17. Stott.G; Hookworm infection and anaemia in Mauritius: Trans. Roy.Soc.Trop.Med.Hyg;55:2025.1960 .

18. Martin,L.K; Hookworm in Geogria. Survey of intestinal helminthic infections and anaemia in rural school children. Amr.Jr.Trop.Med.Hyg;216)46- 
49.1972.

19. Balows, A and Hausler; J; Diagnostic procedures for bacterial, mycotic and parasitic infections. 6th Ed.American Pub. Hith.Assoc.1015.Fifteeenth street, N.W, Washington D.C. 20005:1100-1104-1981.

20. Crewe, W; A guide to human parasitology 10th.E.D. English language Book society, London:184186.1985

21. Wittman, K.S and John, C.T; Medical laboratory skills. Gregg Davidson-Mc Graw hill Book company, New York: 106-132-1977.

22. Weinkove, C; and McDowell.D.R; Porphyrins, haemoglobin and related compounds in: Govenlock, A.H, Me Murray, J.R and Mclauchlan, D. M; Edits.
Varley's practical clinical bio chemistry.6th Ed Heinemann medical books, London;642-669.1988.

23. Raphael, S.S; Lynch's medical laboratory technology 4th Ed; W.B. Saunders CO; Philadelphia, U.S.A. 672-699.1983.

24. Pakistan medical research council. Official journal of P.M.R.C; Research on National Health Problems 41: 1986.

25. W.H.O.: Requirement of ascorbic acid, Vitamin D, Vitamin B12, Folate and Iron. W.H.O. technical report series. 1970 .

26. Gold smith,G.A; Current status of malnutrition in the tropics. Amr. Jr. Trop. Med.23(4):25-47.1971. 